\title{
Deaths due to Lightning Strikes: A Retrospective Study of a Ten-year Period (2007-2017)
}

\author{
Yıldııım Çarpmasına Bağlı Ölümler: 10 yıllık Retrospektif bir çalışma (2007-2017)
}

\section{(D) Hüseyin Çetin Ketenci MD.1, (1) Mehmet Altınok MD.2, (1) Emel Çakır Assoc. Prof. MD. ${ }^{3}$, (D) Halil ilhan Aydoğdu MD.4, (D) Nazım Ercüment Beyhun Prof. MD.5}

${ }^{1}$ The Ministry of Council of Forensic Medicine Trabzon Group Chairmanship, Trabzon, Turkey

2The Ministry of Justice Council of Forensic Medicine, Istanbul, Turkey

${ }^{3}$ Karadeniz Technical University Faculty of Medicine, Department of Pathology, Trabzon, Turkey

4The Ministry of Justice Council of Forensic Medicine, Istanbul, Turkey

${ }^{5}$ Karadeniz Technical University Faculty of Medicine, Department of Public Health, Trabzon, Turkey

\section{ABSTRACT}

Objective: Lightning is a major reason for weather-related deaths and injuries. The risk of being struck by lightning is higher for those who work outdoors.

Methods: In this retrospective study, 19 lightning-related deaths between 2007 and 2017, which were obtained from the archives of Council of Forensic Medicine Trabzon Group Chairmanship, were evaluated.

Results: The age range of the cases was between 8 and 75 years and 15 of them were male. Nine of the cases were a shepherd. The number of the cases went to the top in June with nine cases and 17 of the decedents were found in outdoor spaces. On the external examinations of eight cases (42\%), there was a Lichtenberg figure. The electrical entrance regions were the head and neck in 10 cases (53\%). Bleeding, contusions and lacerations, especially in the lungs and brain, were considered to be due to the blast effect of the lightning. Subepidermal/suprabasal dissociation, spindle appearance in epithelial cells of epidermis and dermal appendages, intraepidermal vesicles and collagen denaturation were detected in microscopic examinations.

Conclusion: Lightning is an airborne event that may cause death in outdoor environments. After a lightning strike, a Lichtenberg figure can be seen on external examination, and macroscopic bleeding in the lungs and brain can be observed on internal examination. It will be beneficial to provide basic awareness training on lightning strike risks for the whole society, especially for shepherds and agricultural workers, to reduce the deaths due to lightning strikes, the exact death causes of which can be determined through autopsies.

Keywords: Autopsy, lightning, death, lichtenberg figure, electrical entrance wound 


\section{Öz}

Amaç: Yıldırım, hava koşullarına bağlı ölüm ve yaralanmaların önemli bir nedenidir. Yıldırıma çarpılma riski dış ortamda çalışanlarda daha yüksektir.

Yöntem: Çalışmada 2007-2017 yılları arasında gerçekleșen ve Adli Tıp Kurumu Trabzon Grup Başkanlığı'na otopsisi yapılmak üzere gönderilen olgulardan elde edilen 19 yıldırım düşmesi olayı, arşivlerinden retrospektif olarak taranarak değerlendirildi.

Bulgular: Olguların yaș aralığı 8-75 iken 15’i erkekti ve 9'u çobandı. Olgu sayısı Haziran ayında 9 ile pik yapmıștı. Ölenlerin 17'si açık alanlarda bulundu. Olguların 8'inin (\%42) dış muayenesinde lichtenberg figürü bulgusu vardı. On olguda elektrik giriș bölgesi baș ve boyun (\%53) idi. Akciğerlerdeki ve beyindeki kanama, kontüzyon ve laserasyonların yıldırımın patlama etkisine bağlı olarak oluştuğu düşünüldü. Mikroskobik incelemelerde subepidermal/suprabazal ayrıșma, epidermis ve dermal eklerin epitel hücrelerinde iğsi görünüm, intraepidermal veziküller ve kollajen denatürasyonu tespit edildi.

Sonuç: Yıldırım genellikle dış ortamlarda ölüme neden olabilen, hava kaynaklı bir olaydır. Yıldırım çarpması sonrasında dış muayenede Lichtenberg figürü, iç muayenede ise akciğerlerde ve beyinde makroskopik düzeyde kanama görülebilir. Kesin ölüm nedenleri yapılan otopsiler sonucunda tespit edilebilen yıldırım çarpmasına bağlı ölümlerin azaltılmasına yönelik olarak çobanlar, tarım ișçileri bașta olmak üzere tüm topluma yönelik yıldııım çarpması risklerine karșı temel farkındalık eğitimlerinin verilmesi faydalı olacaktır.

Anahtar Kelimeler: Otopsi, yıldırım, ölüm, Lichtenberg figürü, elektrik giriş yarası

\section{INTRODUCTION}

Sudden and visible discharge that occurs between the cloud and the earth is called lightning (1). The lightning arises from cumulonimbus type clouds, which develop only near the surface of the earth and grow vertically in unstable weather (2). Electrical discharge may be fatal to humans with enormous electrical energy potentials and high temperatures. During electrical discharge, the temperature in the lightning line can rise up to $28,000{ }^{\circ} \mathrm{C}$. When high temperature forces the air to expand rapidly, it causes thunder and blast effect (3).

Electric current disrupts cell membrane positivity and function, and at the same time, turns into heat as it passes through body tissues (4). The severity of the tissue damage that arises from the current; directly related to factors, such as voltage, exposure time and tissue resistance (5). It is stated that bone, fat tissue, tendon, skin, muscle, veins and nerves show the most resistance to electric current (6). Fatal injuries are seen in high voltage currents, but also in household low voltage currents, ventricular fibrillation, asystole, respiratory muscle paralysis or sudden death may occur as a result of passing through the brain and brain stem (7-9). Blunt wounds can also be observed in lightning strikes due to the explosive effect of the shock wave created by the ionized air (10).

Approximately 100 lightning occur each second worldwide. It occurs especially during the summer and at noon (11). It was reported that 1,318 people died due to lightning strike in the United States between 1980 and 1995, and only in New Mexico, 374 people lost their lives due to lightning strike between 1995 and $2000(12,13)$.

There are several studies about lightning strikes in Turkey in the literature. Among all autopsies, the rate of deaths due to lightning strike was $0.3 \%$ in Eskişehir and $0.7 \%$ in Diyarbakır. In addition, in another study, it was reported that in the period between 2003-2007, seven autopsy cases died as a result of the lightning strike in Trabzon (14-16). Other studies in Turkey were case reports (17-20).

Although lightning deaths that occur due to electrical contact are rare, the people who died were hikers and workers in the outdoor spaces, such as shepherding, farming and construction workers (11,21). Lightning may occur directly onto people or an object and affect those who have contact with it. Electrical current may also cause electrothermal injuries and death by splashing or moving on the ground. In addition, it may lead to an explosive effect (i.e., a blast effect) around it and cause death by falling down or crushing $(14,17,22)$.

If lightning affects the people directly, death cause is usually cardiac arrest and respiratory paralysis $(11,23)$. Since medical evidence cannot be found in such cases, witness information about the area where the event took place may be significant (24).

Pathognomonic findings of lightning strike are usually pink lesions, which fern-like branching structures formed in external examination. This finding is called arborization or Lichtenberg figure. This finding is related to dilatation or rupture of the vessels under the skin and the extravasation of blood from the vessels. Electrical current tends to follow the shortest and the least resistant path for itself, and therefore, follows the vein traces $(17,25)$.

Metal objects on the person may be magnetized, heated, melted, combined, and the clothing on the person may be torn, burned and wetted by rain after the contact with lightning $(11,14,24)$.

The electrical entrance and exit findings may appear as sole tearing. The conduction type and thermal burns associated with the electrical current may be seen, but deep burns like carbonization usually do not occur because lightning strike takes a short time. Burnt areas may also be observed on the 
body surface depending on burnt clothes. Some injuries may occur in the tympanic membrane due to the blast effect (14).

Visceral contusions and hemorrhages may occur especially in the brain and lung. Bone fractures arise from both blast effect and excessive contraction of muscles $(19,25)$. In the histopathological examination of skin samples, thermal vacuoles in the stratum corneum and breakdowns in some areas, elongation of the cells in the same direction in stratum basale, and homogenization in stratum spinosum may appear (25-27).

is the present study aims to evaluate the deaths that arise from lightning that reported at Council of Forensic Medicine Trabzon Group Chairmanship, which is located in the wettest region of Turkey within a 10-year in the light of the literature. The chairmanship is the autopsy center where the forensic cases are sent from the neighboring cities.

\section{MATERIALS and METHODS}

The files of 8,503 autopsies, which were performed between 01.09.2007 and 31.08.2017 that obtained from the archives of Council of Forensic Medicine Trabzon Group Chairmanship were evaluated, and 19 cases related to lightning were selected. In this retrospective study, the data were collected on demographic characteristics of the victims, such as age, gender, occupation, place of the event, season and event time, features of the area, weather conditions, presence of the other injured or dead creatures due to lightning strike at the scene, witness statements about the lightning -if any-, information sent by judicial authorities about the place of the event, the status of clothes and metal accessories, findings arise from metal accessories, external examination of the autopsy, presence of visceral organ damage, and histopathological - toxicological findings.

\section{Statistical Analysis}

Statistical analyses were performed using the SPSS 23.0 program. The descriptive statistics ( $\mathrm{n}, \%$, mean and standard deviation) were used to present the characteristics of the cases.

\section{RESULTS}

The findings showed that $19(0.22 \%)$ of the 8,503 autopsies performed at Council of Forensic Medicine Trabzon Group Chairmanship were the deaths caused by lightning strike in 10 years. The age range of the cases was 8-75, and the average was $28.15 \pm 17.28$. Fifteen cases (79\%) were male and four cases (21\%) were female. Two cases were foreign nationals.

There was no information about the occupation of five cases, nine of the remaining 14 cases (64\%) were shepherds or students who routinely worked as shepherds on holidays and three of them were only students, one was an agricultural worker and one was a farmer. It was seen that 11 of the cases (79\%) whose jobs related to agriculture and raising livestock.
Two (11\%) of fatal lightning strikes occurred in May; nine (47\%) in June, two (11\%) in July, one (5\%) in August and five (26\%) in September. The number of the cases peaks in June with nine cases; and in September with five cases (Figure 1).

Seventeen of the deaths (89\%) occurred in outdoor spaces, such as plateau, pasture, field, house garden or out of town, one of the remaining two cases was in a tent and the other one was in a hut that had not a strong structure.

In the twelve cases, there were also eye-witnesses who testified to what happened (63\%) and who gave information about the certain time of the event. All of these 12 cases, whose time was known, occurred between $1 \mathrm{pm}$ and $6 \mathrm{pm}$ and two third of the cases (67\%) of occurred between $4 \mathrm{pm}$ and $6 \mathrm{pm}$ (Figure 2). There was no witness that would give any information for other seven people that were found between $6 \mathrm{pm}$ and $7 \mathrm{am}$.

There was some information about the weather in the files of 11 cases (58\%) and eight of them (73\%) said that there was rain or rainstorm at the time of incident, while for the remaining three cases (27\%), it was reported that it started to rain soon after the event.

In the files of four cases, next to victim, there was another person who survived with injuries, and one of the cases includes 46 sheep and their shepherd death. Only three of the cases did not die at the scene, they died in the hospital after a while. In this study, three of 19 cases received treatment. Common microscopic finding in these three cases were bleeding and edema in the breast or abdominal organs as it was same for 15 cases that were died at the place of event. The cases



Figure 1. Distribution of the cases by months



Figure 2. Number of cases by time of day 
that have intracranial bleeding or internal organ contusion died on the place of the event, only those who have internal organ bleeding or edema were removed to the hospital. In six of the eight cases $(75 \%)$ had some findings of their clothes such as burns and tears that might occur by lightning. In one case, some burns were observed on the skin and there were located under the belt buckle (Picture 1).

On the external examinations of eight cases (42\%), Lichtenberg figure was seen that was considered as pathognomonic for the lightning strike; and at the autopsy of 12 cases (63\%), it is reported that their hairs and body hairs were fumigated (Picture 2 and 3). One of the cases had otorrhagia, which could be a finding of tympanic membrane damage caused by the blast effect.

One of the cases was found died in the outdoor space while was working with gloves, and his radio was hanging on his neck (Picture 4). On the external examination, it was seen that the clothes under the radio were torn, which made us consider that the radio, as an electronic device, attracted lightning (Picture 5).

There were macroscopic findings that indicate electrical entrances on all cases' bodies. The localizations of these lesions, which were defined as electrical entrance, were head in seven cases, neck in three cases, chest in four cases, thoracolumbar region in three cases and upper extremity in two cases. The electrical entrances were head and neck regions in 10 cases (53\%) and were the upper half of the body in the whole cases. Findings, such as hyperemia, burning, peeling of the skin and keratinized-crater structure, were detected at the point of entry. The most common findings were hyperemia and burn that were found in twelve cases' bodies (63\%). There was skin peeling in four cases (21\%), and keratinized-crater structure in three cases (16\%). Nine of the cases (47\%) had only one finding.

Electrical entrance and exit wounds were detected in the 14 cases' bodies (74\%). The regions of exit wounds were feet in 10



Picture 1. Dermal burn at the belt buckle region. cases, upper extremity in two cases, and femur in two of them. The electricity left the body from the lower half of the body in 12 of the cases (86\%). Findings, such as hyperemia, burns, skin peeling and keratinized-crater structure, were seen at the region of exit. The most common findings in this region were keratinized-crater in nine cases (64\%), hyperemia in four cases (29\%), and burns and skin peeling in two of them (14\%).

On the macroscopic examination of visceral organs, some findings related to lightning were detected. Bleeding, contusions and lacerations, especially in the lungs and brain, were considered to be due to the blast effect of the lightning (Picture 6). Edema and hemorrhage were found on the histopathological examination of visceral organs of 18 cases $(95 \%)$, intracranial hemorrhage was found in three of them (16\%) and visceral contusion in one case (5\%).

On the histopathological examination of the skin of the 18 cases (95\%), there were one or more findings related to electrical conduction and heat effect, such as subepidermal blistering, elongation of the epidermis and dermis cell, intraepidermal vesicles and collagen denaturation (Picture 7).

No bone fractures were found in any body part of the cases. No evidence of alcohol or narcotic-narcotic substances was found

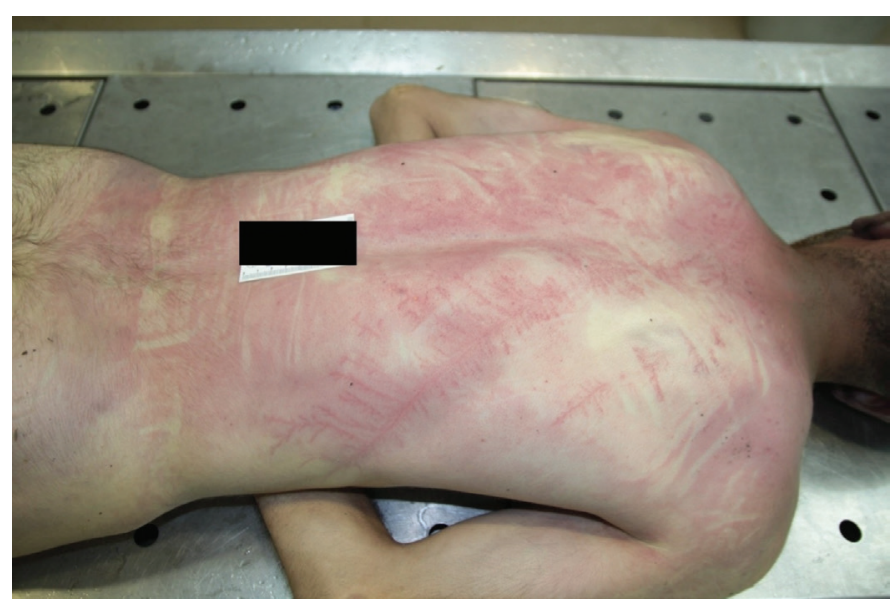

Picture 2. Lichtenberg figure

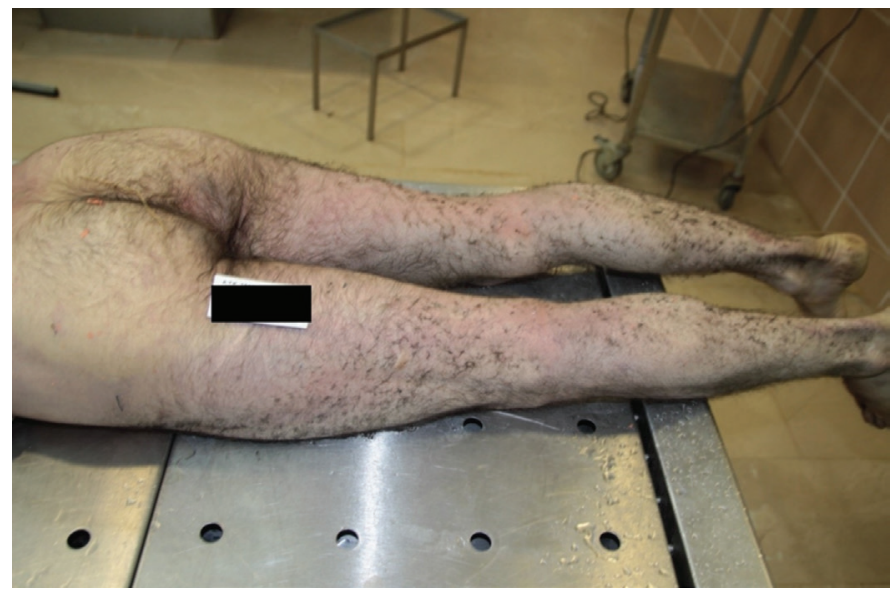

Picture 3. Fumigation of body hairs 
in the toxicological analysis of body fluids. The findings of 19 cases are shown in Table 1.

\section{DISCUSSION}

The incidence of deaths due to lightning strikes in all autopsies was consistent with the national literature $(0.22 \%)$. This rate was $0.3 \%$ in the study conducted by Akkaya et al. (14) in Eskișehir; and $0.7 \%$ in the study conducted by Tırașçı et al. (15) in Diyarbakır.

According to the analysis of demographic data, the majority of the cases were farmer men and the rest of the cases were those who were interested in nature sports and hiking (11-15). Seven of eight cases in the study conducted by Akkaya et al. (14) in Eskişehir, all of the seven cases in the study conducted by Turan et al. (16) in Karadeniz; and two of three cases in the study conducted by Doğan et al. (18) in Konya were male; and all of them were farmer (15). These results are consistent with the findings of this study. These data reveal risky professions and occupations concerning lightning strike. Accident risks should be reduced by informing people who are at risk due to their profession (e.g., forestry worker, farmer and shepherd). In addition, precautions should be taken in hobby activities.

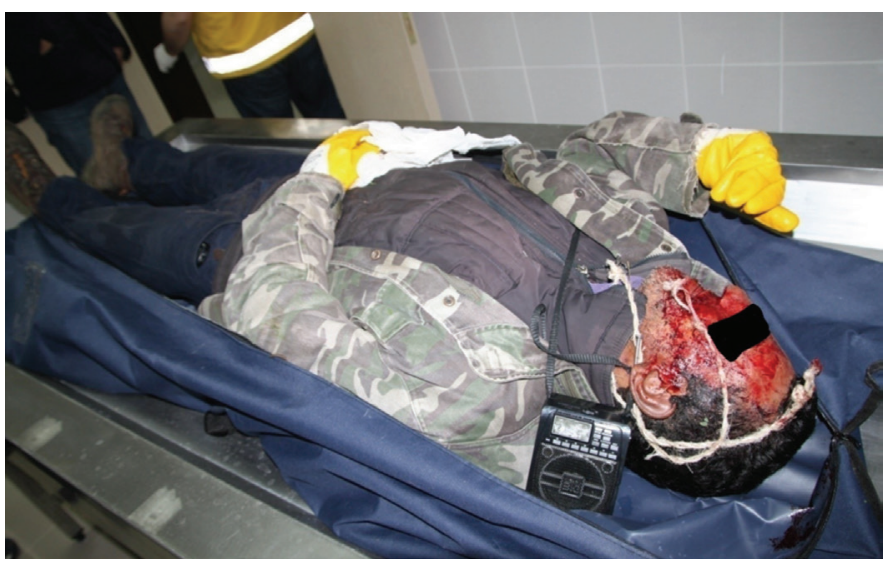

Picture 4. The case that had a radio hanging on his neck

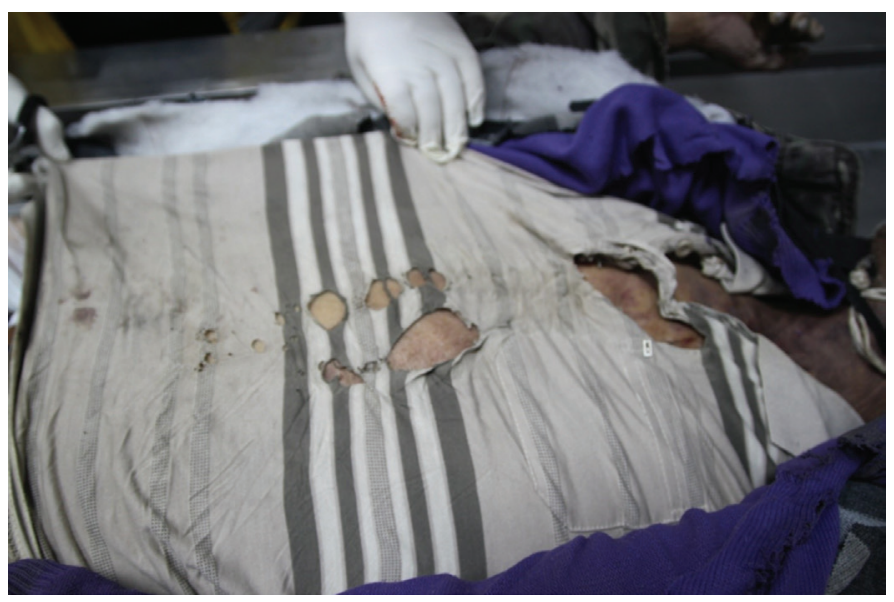

Picture 5. Torn clothes in the localization of the radio in the case that had a radio on his neck
All of the 19 deaths due to lightning strikes occurred in five months between late spring and early fall, including the summer season, between May and September, and in the outdoor spaces, such as fields, gardens, plateaus or meadows and in tents or huts. In studies conducted previously in Turkey, it was reported that all of the deaths that arise from lightning happened in the outdoor spaces or in tents and huts in a period that included summer similarly $(14,16,17,19)$.

The cities that the events take place are the cities of the Black Sea coastal line, which are exposed to heavy rainfall, or the cities which have a wide range of pastures and meadows, and it is common to raising livestock. These results reflect the nature of the lightning and the deaths associated with it like reported in the international literature. In this region, deaths of livestock due to lightning are observed together with the deaths of victims who work in animal husbandry (22). Similarly, it is consistent with the literature, in two-thirds of the cases occurred between $4 \mathrm{pm}$ and $6 \mathrm{pm}$, and all of them were in rainy and stormy weather or just before the rain (11). In studies previously performed in Turkey, it was reported that the weather was rainy or stormy; and in cases without information about the weather, it was reported that the clothes of the cases were wet and muddy, which is consistent with rainy weather $(12,14,17,18)$.

It was determined that in $12(63 \%)$ of the cases, there were witnesses who were not affected by lightning, and in four cases (21\%), there were survivors although they were exposed to lightning. It is clear that receiving basic life support training

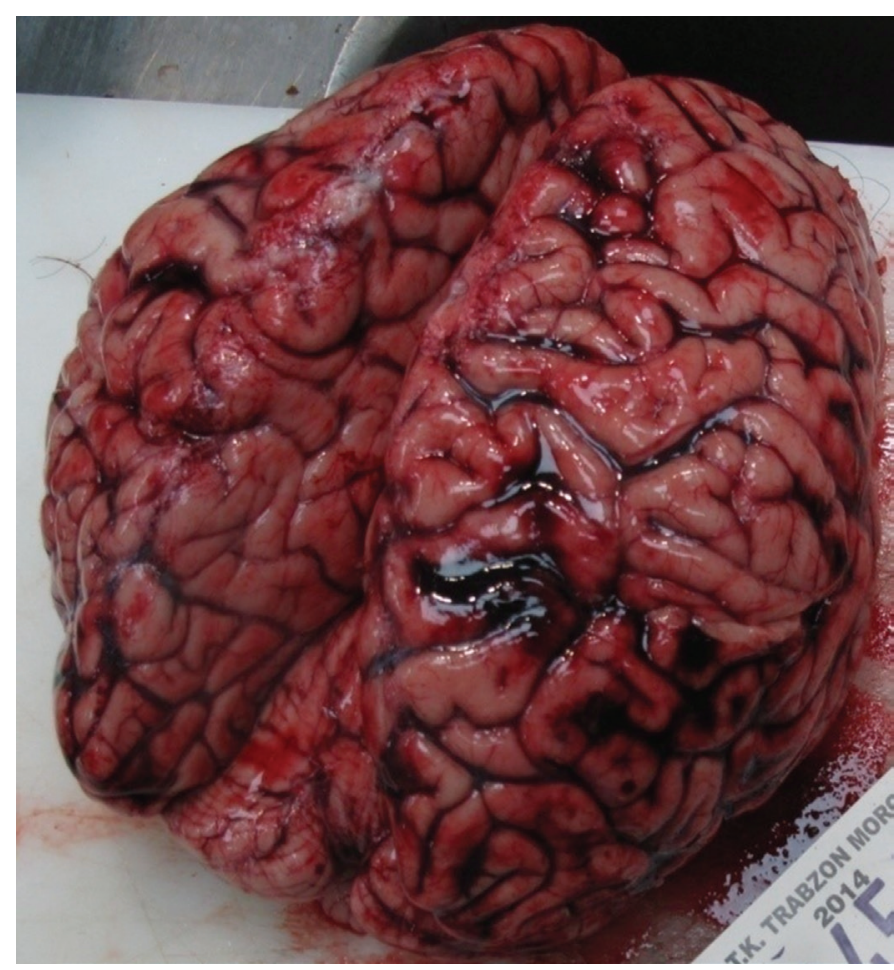

Picture 6. Subarachnoid bleeding was considered to occur due to the blast effect 


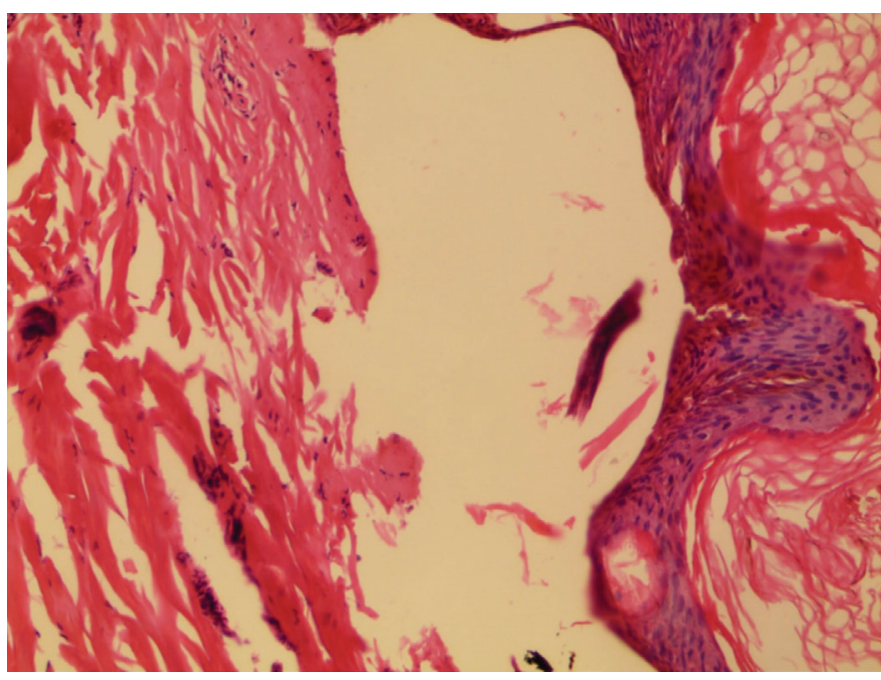

Figure 7. Subepidermal blistering, elongation of cells, intraepidermal vesicles and collagen denaturation (HEx200) can provide significant benefits in such situations and giving first aid and calling an ambulance can reduce mortality rates. Lichtenberg figure, which is a pathognomonic finding of the lightning strike may not appear in every case. In the present study, this finding was found in eight cases (42\%) and it is consistent with the literature. This rate was $29 \%$ in a previous study conducted in the Black Sea Region and 50\% in the study conducted in Eskișehir $(14,16)$.

In the only case which had otorrhagia, there was no dome or base of skull fracture or intracranial hemorrhage, and no other signs of bleeding in the external acoustic meatus and in the auricle. Although it was not performed otoscopic examination at the autopsy, it was considered that detecting a small amount of otorrhagia without intracranial hemorrhage in a single case might be due to the perforation of the tympanic membrane result from the blast effect of the lightning.

\begin{tabular}{|c|c|c|c|c|c|c|c|c|c|}
\hline Case & $\begin{array}{l}\text { Male } \\
\text { gender }\end{array}$ & $\begin{array}{l}\text { Outdoor } \\
\text { space }\end{array}$ & $\begin{array}{l}\text { Rainy } \\
\text { weather } \\
\text { status }\end{array}$ & $\begin{array}{l}\text { Electrical } \\
\text { entrance } \\
\text { wound }\end{array}$ & $\begin{array}{l}\text { The point of } \\
\text { entry in the } \\
\text { upper half of } \\
\text { the body }\end{array}$ & $\begin{array}{l}\text { Electrical } \\
\text { exit } \\
\text { wound }\end{array}$ & $\begin{array}{l}\text { The point of } \\
\text { entry in the } \\
\text { lower half of } \\
\text { the body }\end{array}$ & $\begin{array}{l}\text { Lichtenberg } \\
\text { figure }\end{array}$ & $\begin{array}{l}\text { Microscopic } \\
\text { findings of heat } \\
\text { effect on the skin }\end{array}$ \\
\hline 1 & + & + & $\begin{array}{l}\text { No } \\
\text { information }\end{array}$ & + & + & + & + & + & + \\
\hline 2 & + & + & $\begin{array}{l}\text { No } \\
\text { information }\end{array}$ & + & + & + & + & + & + \\
\hline 3 & - & \begin{tabular}{|l|}
- \\
(Tent)
\end{tabular} & + & + & + & + & + & - & + \\
\hline 4 & + & + & $\begin{array}{l}\text { No } \\
\text { information }\end{array}$ & + & + & + & + & + & + \\
\hline 5 & + & + & $\begin{array}{l}\text { No } \\
\text { information }\end{array}$ & + & + & + & + & - & + \\
\hline 6 & + & + & $\begin{array}{l}\text { No } \\
\text { information }\end{array}$ & + & + & + & + & + & + \\
\hline 7 & + & + & + & + & + & + & + & - & + \\
\hline 8 & - & + & + & + & + & + & - & - & + \\
\hline 9 & - & + & + & + & + & - & \begin{tabular}{|l|} 
No lesions \\
\end{tabular} & - & - \\
\hline 10 & + & + & + & + & + & - & No lesions & - & + \\
\hline 11 & + & + & + & + & + & - & No lesions & - & + \\
\hline 12 & + & + & $\begin{array}{l}\text { No } \\
\text { information }\end{array}$ & + & + & + & + & - & + \\
\hline 13 & + & + & $\begin{array}{l}\text { No } \\
\text { information }\end{array}$ & + & + & + & + & - & + \\
\hline 14 & + & + & $\begin{array}{l}\text { No } \\
\text { information }\end{array}$ & + & + & + & + & - & + \\
\hline 15 & + & \begin{tabular}{|l|}
- \\
(Hut) \\
\end{tabular} & + & + & + & + & + & + & + \\
\hline 16 & + & + & + & + & + & + & - & + & + \\
\hline 17 & + & + & + & + & + & - & No lesions & - & + \\
\hline 18 & - & + & + & + & + & - & No lesions & + & + \\
\hline 19 & + & + & + & + & + & + & + & + & + \\
\hline
\end{tabular}


Although it is not always possible to demonstrate sudden cardiac and pulmonary arrest on macroscopic and microscopic examination, it is possible to explain the cause of death in all cases by detailed information obtained from the scene, external examination and histopathological examination.

\section{Study Limitations}

As this study is based on reported files of the cases, the witness statements and crime scene photos could not be found in some of the files during the retrospective investigation.

\section{CONCLUSION}

This study is valuable in that this study has shown that the team to make the autopsy in lightning strike cases must obtain the data of the place of the event, the weather conditions at the time of the event, the presence of other living beings injured at the place, and the features of the clothes of the victims before the autopsy. The team should also perform a detailed external examination and consider especially the Lichtenberg figure, fumigated hairs, and must take samples from the entrance and exit wounds.

In light of our findings, we suggest that several precautions should be taken against this fatal natural event, which is partly foreseeable for those who are more likely to be at risk of expose to lightning because of their job or the region they live. No matter whether the individuals live in the city or in rural areas, increasing awareness in this field, basic training about simple security measures that every person (especially shepherds) can receive may provide significant benefits to reduce human and animal deaths caused by lightning.

\section{Ethics}

Ethics Committee Approval: This study was reviewed and approved by The Ministry of Justice Council Of Forensic Medicine Research \& Ethics Committee (21589509/2017/586) and Helsinki Declaration rules were followed to conduct this study.

Peer-review: Internally peer-reviewed.

\section{Authorship Contributions}

Concept: H.Ç.K., M.A., E.C.., H.I.A., N.E.B., Design: H.Ç.K., M.A., E.C.., H.I.A., N.E.B., Data Collection or Processing: H.Ç.K., M.A., N.E.B., Analysis or Interpretation: H.Ç.K., E.C.., H.I.A., N.E.B., Literature Search: H.Ç.K., M.A., E.C.., H.I.A., N.E.B., Writing: H.C..K., M.A., E.C.., H.I.A., N.E.B.

Conflict of Interest: No conflict of interest was declared by the authors.

Financial Disclosure: The authors declared that this study received no financial support.

\section{REFERENCES}

1. Eken M, Ulupınar Y, Demircan M, Nadaroğlu Y, Aydın B, Özhan U. Klimatolojik Rasat El Kitabı. Ankara: Devlet Meteoroloji Genel Müdürlüğü Matbaası; 2008:342.
2. Köksal S. Bulutlar. Ankara: Devlet Meteoroloji Genel Müdürlüğü Matbaası; 2007:66.

3. Eken M, Ceylan A, Taștekin AT, Șahin H, Şensoy S. Klimatoloji II. Ankara: Devlet Meteoroloji Genel Müdürlüğü Matbaası; 2005:4-5.

4. Rice P, Orgill D.P, Jeschke M, Collins K. Assessment and classification of burn injury. Last Accessed Date: 10.08.2020. Available from: https://www. uptodate.com/contents/classification-of-burn-injury

5. Saukko P, Knight B. Knight's forensic pathology. $4^{\text {th }}$ ed. USA: CRC Press; 2016.

6. Chilbert M, Maiman D, Sances JA, Myklebust J, Prieto TE, Swiontek T, et al. Measure of tissue resistivity in experimental electrical burns. J Trauma. 1985;25(3):209-215. https://doi.org/10.1097/00005373-198503000-00007

7. Carleton S. Cardiac problems associated with electrical injury. Cardiol Clin. 1995;13(2):263-266.

8. Güloğlu C, Orak M, Altuncı YA. Electric injury and burns. Turk J Med Sci. 2007;3(1):84.

9. VanDenburg S, McCormick GM. $2^{\text {nd }}$, Young DB. Investigation of deaths related to electrical injury. South Med J. 1996;89(9):869-872.

10. Kök N. Türk Ceza sisteminde adli tıp uygulamaları. $1^{\text {st }}$ ed. Ankara: Seçkin Yayıncılık; 2014

11. Pincus JL, Lathrop SL, Briones AJ, Andrews SW, Aurelius MB. Lightning deaths: a retrospective review of New Mexico's cases, 1977-2009. J Forensic Sci. 2015;60(1):66-71. https://doi.org/10.1111/1556-4029.12546.

12. Centers for Disease Control and Prevention (CDC). Lightning-associated deaths-United States, 1980-1995. MMWR Morb Mortal Wkly Rep. 1998;47(9):391-394.

13. Adekoya N, Nolte KB. Struck-lightning deaths in the United States. J Environ Health. 2005;67(9):45-50.

14. Akkaya H, Karbeyaz K, Kökçüoglu MA, Urazel B. Lightning associated deaths during 1997-2011 in Eskisehir. J For Med. 2013;27(2):94-99. https://doi. org/10.5505/adlitip.2013.98853.

15. Tırașc $Y$ and Gören S. An analysis of the medicolegal deaths performed in Diyarbakir, in 1996-1998. Dicle Med J. 2005;32(1):1-5.

16. Turan N, Birincioglu I, Bütün C, Can M. Findings in fatal lightning strike cases. Turkiye Klinikleri J Foren Med. 2011;8(2):59-65.

17. Özsoy S, Tuğcu H, Toygar M, Safalı M. Skull fracture due to lightning; a death case. J For Med. 2011;25(3):217-222.

18. Doğan HK, Demirci S, Günaydın G. Deaths caused by lightning strike: case report of three cases. General Med J. 2007;17(4):217-222.

19. Demirel B, Yağan M, Balseven A, Cantürk N, Dinç AH. Death by lightning injury: a case report. Gazi Med J. 2007;18:(2):92-94.

20. Bütün C, Beyaztaş FY, Yılmaz R. Lightning-related death. Turk Arc Ped. 2012;47(1):60-63. https://doi.org/10.4274/tpa.1193.

21. Böhrer M, Stewart SA, Hurley KF. Epidemiology of electrical and lightningrelated injuries among Canadian children and youth, 1997-2010: a Canadian Hospitals Injury Reporting and Prevention Program (CHIRPP) study. CJEM. 2018;20(4):586-591. https://doi.org/10.1017/cem.2017.49.

22. Vanneste E, Weyens P, Poelman D.R, Chiers K, Deprez P, Pardon B. Lightning related fatalities in livestock: Veterinary expertise and the added value of lightning location data. Vet J. 2015;203(1):103-108. https://doi.org/10.1016/j. tvjl.2014.10.024.

23. Ventura F, Barranco R, Bonsignore A and De Stefano F. A unusual lightning death in an indoor setting. Am J Forensic Med Pathol. 2017;38(1):1-4. https://doi.org/10.1097/paf.0000000000000273.

24. Eke M, Soysal Z. Fiziksel zararlar. Içinde: Soysal Z, Cakalır C, editörler. Adli Tıp II. İstanbul: İstanbul Üniversitesi Cerrahpaşa Tıp Fakültesi Yayınları: 1999. p.751-753.

25. Albek E. Fiziksel zararlar. İçinde: Adli tıp ders kitabı. İstanbul: İstanbul Üniversitesi Cerrahpaşa Tıp Fakültesi Yayınları; 2011:369-371.

26. Dettmeyer RB. Forensic histopathology, fundamentals and perspectives. Frankfurt, Germany: Springer-Verlag Berlin Heidelberg; 2011:158-159.

27. Cummings PM, Trelka DP, Springer KM. Forensic histopathology. Cambridge: Sevil Press; 2013:89-91. 